\title{
Fabrication of Annealing-Free High Efficiency and Large Area Polymer Solar Cells by Roller Painting Process
}

\author{
Jae Woong Jung, Won Ho Jo* \\ Department of Materials Science and Engineering, Seoul National University, Seoul, Korea \\ * Corresponding author. Tel: +8228807192, Fax:+8228766086, E-mail:whjpoly@snu.ac.kr
}

\begin{abstract}
The polymer solar cells were fabricated by a novel solution coating process, the roller painting. The roller painted film composed of poly(3-hexylthiophene) (P3HT) and [6,6]-phenyl-C61-butyric acid methyl ester (PCBM) has smoother surface than the spin coated film. Since the roller painting is accompanied with shear and normal stresses and is also a slow drying process, the process induces effectively crystallization of P3HT and PCBM. Both crystalline P3HT and PCBM in the roller painted active layer contribute to enhanced and balanced charge carrier mobility. Consequently, the roller painting process results in higher power conversion efficiency (PCE) of $4.6 \%$ as compared to that of the spin coating $(3.9 \%)$. Furthermore, the annealing-free polymer solar cell (PSC) with high PCE were fabricated by the roller painting process with addition of a small amount of 1,8octanedithiol. Since the addition of 1,8-octanedithiol induces phase separation between P3HT and PCBM and the roller painting process induces crystallization of P3HT and PCBM, the PCE of roller painted PSC is achieved up to $3.8 \%$ without post-annealing.
\end{abstract}

Keywords: Roller Painting, Thin Films, Polymer Solar Cells, Device Performance

\section{Introduction}

Polymer solar cells (PSCs) provide special opportunities for low cost, printable, light-weight, flexible, and portable energy source [1]. Over the last decade, these advantages of the PSCs have encouraged intensive research on PSCs, and as a result remarkable improvement has been achieved by molecular engineering, morphology control, and device optimization [2-6]. To date, the power conversion efficiency (PCE) over 5\% has been obtained by using poly(3hexylthiophene) (P3HT) or various low-bandgap polymers as a donor and [6,6]-phenyl- $\mathrm{C}_{60^{-}}$ butyric acid methyl ester (PCBM) as an acceptor [7-10]. Therefore, the P3HT/PCBM combination is one of very promising candidates for commercialization of PSCs.

For commercialization, however, the fabrication process for mass production must be developed [11,12]. Most of the PSCs are manufactured through the spin coating process. Although the spin coating is very useful for fabricating very thin and homogeneous film and for controlling the film thickness [13], the spin coating process has several detrimental problems with mass production. First, the spin coating is not only difficult to scale up but also impossible to fabricate flexible devices. Second, the cost of the process is high, because the spin coating process causes inevitably waste of materials, and furthermore the cost of process increases exponentially as the substrate size increases. Third, as the spin coating is not a continuous process, this process has serious limitation for industrial production.

To overcome these problems, various methods for fabrication of PSCs have been proposed including doctor blading [14,15], ink-jet printing [16], spray coating [17-20], screen printing [21] and brush painting [22]. Although these processes have an advantage for fabrication of large area films and exhibit comparable performance to the spin coating, the thickenss control and inhomogeneity of the film still remain unsolved. In spray coating and brush painting, the film uniformity is not satisfactory. Particularly, the quality of thin film in large area cannot be guaranteed through these processes. Therefore, the development of alternative solution process which is low-cost, easy-to-use and continuous is strongly 
demanded.

The roller painting process is easy-to-use, high throughput and the most widely used method for conventional painting. The substrate size for the roller painting is limitless, and the process cost is also low since the roller painting is a continuous process. Especially, an advantage of the roller painting compared to other coating processes is easiness to control film thickness and uniformity. Since the roller painting is very promising process for the industry of thin film fabrication, it can be used for fabrication of organic electronics including PSCs. In this work, we report the PSCs fabricated by the roller painting, primarily based on our previous report [23].

Furthermore, the roller painting process has another advantage in development of active layer morphology in PSCs, because the process is accompanied with shear and normal stresses. It is well known that the crystalline polymer such as P3HT can be effectively crystallized when the shear or normal stress such as nano rubbing, molecular reflow and nano imprinting is applied [24]. Particularly, Kim et al. [22] have reported that high efficiency PSCs are fabricated by using the brush painting because the shear stress during the brush painting induces the ordering of P3HT chains. Therfore, it is easily expected that the roller painting process which accompanies both the shear and normal stresses induces effectively the crystallization of P3HT and PCBM, and consequently yields enhanced solar cell performance.

\section{Experimental}

\subsection{Materials}

P3HT (Rieke Metals, 90-93\% regioregular) and PCBM (Nano-C, 99.5\%) were used as received. Poly(3,4-ethylenedioxy thiophene):poly(styrene sulfonate) (PEDOT:PSS) (Baytron P VP AI 4083) was purchased from H. C. Stark. For the roller painting process, rubber roller (Hwa Hong) was wrapped with thin PET film to give smooth surface.

\subsection{Fabrication of polymer solar cells}

ITO-coated glass $(15 \Omega / \square)$ was cleaned with acetone and isopropyl alcohol, and then dried at $200{ }^{\circ} \mathrm{C}$ for $30 \mathrm{~min}$. After complete drying, the ITO-coated glass was treated with UV-ozone for $15 \mathrm{~m}$ in, and then PEDOT:PSS was spin coated with $40 \mathrm{~nm}$ in thickness, and the PEDOT:PSS film was annealed at $120^{\circ} \mathrm{C}$ for $30 \mathrm{~min}$ in a $\mathrm{N}_{2}$-filled glove box. P3HT and PCBM (1:1 by weight) were dissolved in o-dichlorobenzene (DCB) with several different concentrations $(2-8 \mathrm{wt} \%)$ to control the thickness of the roller painted thin film. These solutions were stirred for at least $24 \mathrm{~h}$ at room temperature and then were passed through a $0.45 \mu \mathrm{m}$ PES syringe filter before roller painting. The roller painting was processed at room temperature in $\mathrm{N}_{2}$-filled glove box with the roller painting speed of $1 \mathrm{~cm} / \mathrm{s}$, and the roller painting was repeated 5 times. The spin coated PSCs were fabricated at $2500 \mathrm{rpm}$ by using the solution with the same concentration as the roller painting. After complete drying of the active layer, $\mathrm{Al}(100 \mathrm{~nm})$ were thermally evaporated on the top of the active layer under vacuum lower than $10^{-6}$ Torr. The PSC devices were then thermally annealed at $150{ }^{\circ} \mathrm{C}$ inside the glove box. The annealing-free PSC devices were fabricated at room temperature by addition of $5 \mathrm{wt} \% 1,8$-octanedithiol as an additive in the solution of active layer materials. $\mathrm{LiF}(0.7$ $\mathrm{nm})$ was thermally evaporated before the evaporation of Al.

\subsection{Measurement and Characterization}

The UV-visible absorption spectra of roller painted or spin coated P3HT:PCBM films were measured by UV-visible spectrophotometer (HP 8452A). The morphology of the active layer films were observed by TEM (JEOL, JEM-1010 and Tecnai F20). The thickness of thin film was measured by AFM. The crystallinity of active layer was investigated by X-ray 
diffractometer (M18XHF-SRA). The photovoltaic performance was measured under nitrogen atmosphere inside a glove box. The current density-voltage $(\mathrm{J}-\mathrm{V})$ characteristics were measured with a Keithley 4200 source-meter under AM $1.5 \mathrm{G}\left(100 \mathrm{~mW} / \mathrm{cm}^{2}\right)$ simulated by a Newport-Oriel solar simulator. The light intensity was calibrated using a NREL certified photodiode and light source meter prior to each measurement. The IPCE was measured using a lock-in amplifier with a current preamplifier under short circuit current state with illumination of monochromatic light.

\section{Results and Discussion}

To examine the effect of the coating process on the crystallization of $\mathrm{P} 3 \mathrm{HT}$, we compared the XRD pattern of the film fabricated by the roller painting with the film fabricated by the spin coating. The pristine P3HT film fabricated by the roller painting shows very sharp and intense peak at $2 \theta=5.6^{\circ}$ while the spin coated P3HT film exhibits relatively broad and lower peak intensity (see Fig. 1a). Also, the (200) and (300) peaks of as-roller painted P3HT film are more discernible than those of spin coated film, implying that the roller painting process induces higher crystallinity of P3HT than the spin coating process. The P3HT:PCBM blend film prepared by the roller painting also shows stronger and sharper peak than the spin coated films before thermal annealing, as shown in Figure 1b, indicating that P3HT in the blend film is more crystallized in the roller painted film than in the spin coated film. After thermal annealing, the intensity of (100) peak of the spin coated blend film is increased while the (100) peak of the roller painted blend film is nearly unchanged, indicating that P3HT in asroller painted film is sufficiently crystallized during roller painting and thus the crystallization does not take place significantly during thermal annealing.

Since the diffraction angle at $2 \theta=5.5^{\circ}$ corresponds to the (100) packing which is associated with the interdigitation of the alkyl chians of P3HT as shown in Figure 1b [26], the exact interchain spacing between P3HT chains can be determined from the diffraction angle of (100) peak. When the interspacing was calculated by using the Bragg law, the interchain spacings of the roller painted P3HT:PCBM film and the spin coated film are $1.6 \mathrm{~nm}$ and 1.7 $\mathrm{nm}$, respectively. One of reasons for higher crystallinity and closer packing of roller painted film is that the normal and shear stress accompanied with the roller painting induces effectively alignment of P3HT chains which inducess crystallization. Another reason for higher crystallinity of roller painted P3HT is slower drying of P3HT as compared to the spin coating process, which provides more time for P3HT to crystallize. These closely packed P3HT crystals would have an advantage in hopping and transport of hole carrier.

The effect of roller painting on the chain packing of P3HT was also observed by UV-Vis absoprtion spectroscopy (see Fig. 2a). Compared to the spin coated P3HT film, the absorption of the roller painted P3HT film is larger in the range of 520-640 nm wavelength. Since the thicknesses of both P3TH films are controlled the same, the larger absorption of the roller paintied film is origniated from close packing of the roller painted P3HT film [8]. The close packing of the roller painted $\mathrm{P} 3 \mathrm{HT}$ is further evidenced by the distinct vibronic shoulder at $600 \mathrm{~nm}$ which has been assigned to highly delocalized excitation [26].

The absorption difference between the roller painted film and the spin coated film becomes more prominent in the P3HT/PCBM blend film, as shown in Figure 2b. The roller painted blend film exhibits the maximum absorption at $556 \mathrm{~nm}$ with a remarkable vibronic shoulder at $600 \mathrm{~nm}$ while the spin coated film does the maximum absorption at $522 \mathrm{~nm}$ with a weak vibronic shoulder. Moreover, the absorption intensity of the roller painted blend film is stronger than that of the spin coated film. 
(a)

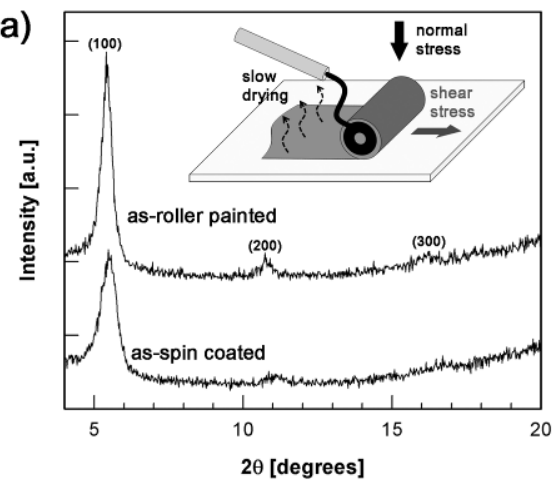

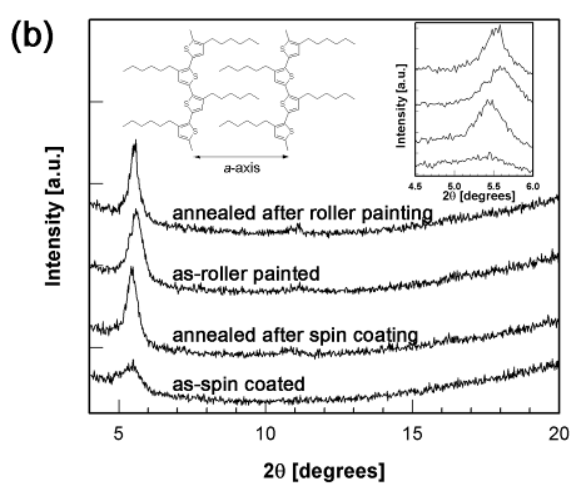

Fig. 1. XRD patterns of (a) P3HT films and (b) P3HT:PCBM films fabricated by the roller painting and the spin coating. Inset of Figure $2 b$ clearly shows the shift of the (100) peak of the roller painted film compared to that of the spin coated film. Schematic illustration in Figure $2 b$ shows the chain packing of regioregular $\mathrm{P} 3 \mathrm{HT}$ in crystallite.

When the samples are annealed at $150{ }^{\circ} \mathrm{C}$ for $15 \mathrm{~min}$, the absorption intensity of the spin coated film is increased, indicating that thermal annealing induces crystallization of P3HT in the blend film, whereas the absorption spectrum of the roller painted film does not increase significantly after thermal annealing. This result is consistent with the XRD measurement which exhibits almost the same crystallinity before and after annealing in the roller painted blend film (Fig. 1b). This high crystallization arising from the roller painting process without thermal annealing provides a very promising feature for the development of annealing-free PSCs for commercialization.
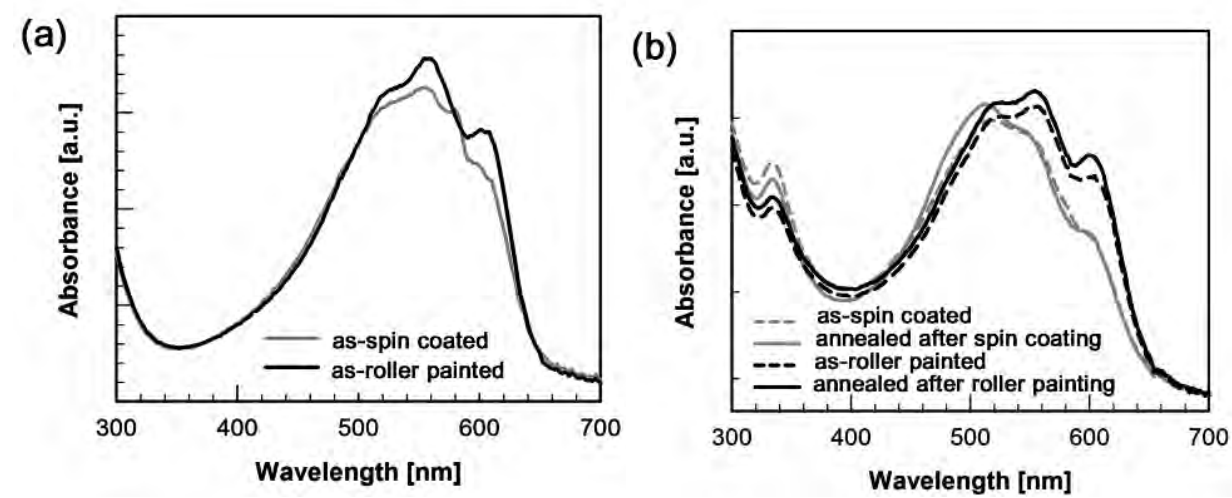

Fig. 2. UV-Vis absorption spectra of (a) pristine P3HT film and (b) P3HT:PCBM blend film fabricated by the roller painting and the spin coating.

The PCEs of the PSCs fabricated by the roller painting process are compared with those of the spin coating process in Table 1 , and the corresponding current density-voltage (J-V) curves are shown in Figure 3a. To rationalize the measured values of the short circuit current density $\left(\mathrm{J}_{\mathrm{SC}}\right)$, we also calculated $\mathrm{J}_{\mathrm{SC}}$ from the incident photon-to-current efficiency (IPCE) measured by using the same device (Fig. $3 b$ ). When the $\mathrm{J}_{\mathrm{SC}}$ values from IPCE were compared with those of device values of $\mathrm{J}_{\mathrm{SC}}$, it reveaed that two values were nearly equal within experimental errors. For the optimization of PCE, the samples are annealed after deposition of Al. The spin coated PSCs show the maximum PCE after thermal annealing for 15-20 min, while the roller painted PSCs show the maximum efficiency after annealing for 6-8 min at $150{ }^{\circ} \mathrm{C}$. The maximum PCE of the roller painted solar cell is $4.6 \%$ which is $20 \%$ higher than the maximum PCE $(3.9 \%)$ of the spin coated PSC. Since $\mathrm{J}_{\mathrm{SC}}$ is nearly equal to that of the spin coated PSC under the optimum device condition, the main reason for higher PCE of the roller 
painted PSC is slightly increased $\mathrm{V}_{\mathrm{OC}}$, and higher fill factor (FF) as compared with that of the spin coated PSC. Although the factors affecting FF are not completely identified yet [27], it has generally been accepted that FF is influenced by the morphology of the active layer, the balance between hole and electron mobility, and the interface of layers in PSC. Since we focused on the balance between hole and electron mobility in this study, we measured the charge transport from the dark current in a single-carrier device.

Table 1. Optimized performance of PSCs fabricated by roller painting or spin coating process. The thickness of the roller painted device and spin coated device are $245 \mathrm{~nm}$ and $230 \mathrm{~nm}$, respectively.

\begin{tabular}{lcllllll}
\hline Process & $\begin{array}{l}\text { Annealing } \\
{[\mathrm{min}]}\end{array}$ & $\begin{array}{l}\mathrm{V}_{\mathrm{OC}} \\
{[\mathrm{V}]}\end{array}$ & $\begin{array}{l}\mathrm{J}_{\mathrm{SC}} \\
{[\mathrm{mA} / \mathrm{cm}]}\end{array}$ & $\begin{array}{l}\mathrm{FF} \\
{[\%]}\end{array}$ & $\begin{array}{l}\mathrm{PCE} \\
{[\%]}\end{array}$ & $\begin{array}{l}\mu_{\mathrm{h}} \\
{\left[\mathrm{cm}^{2} / \mathrm{Vs}\right]}\end{array}$ & $\begin{array}{l}\mu_{\mathrm{e}} \\
{\left[\mathrm{cm}^{2} / \mathrm{Vs}\right]}\end{array}$ \\
\hline $\begin{array}{l}\text { Roller } \\
\text { painting }\end{array}$ & 0 & 0.57 & 7.5 & 0.56 & 2.4 & $5.07 \times 10^{-5}$ & $1.75 \times 10^{-4}$ \\
Spin & 8 & 0.63 & 11.3 & 0.64 & 4.6 & $1.56 \times 10^{-4}$ & $3.90 \times 10^{-4}$ \\
coating & 0 & 0.56 & 6.6 & 0.52 & 1.9 & $6.52 \times 10^{-6}$ & $4.50 \times 10^{-5}$ \\
\hline
\end{tabular}

(a)

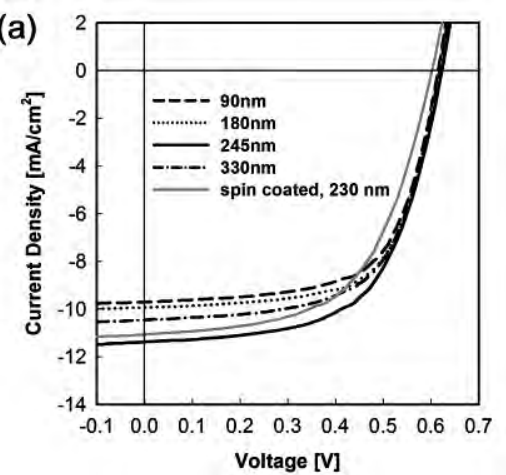

(b)

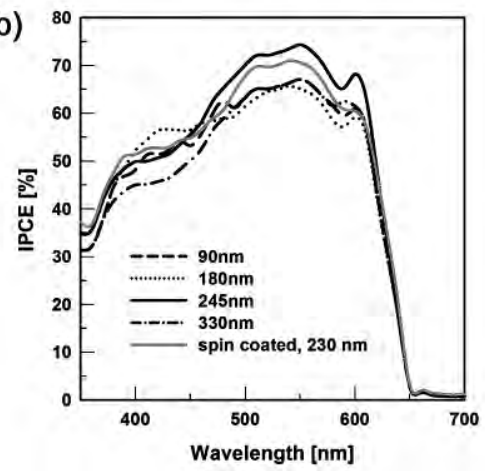

Fig. 3. (a) J-V curves of PSCs $\left(100 \mathrm{~mW} / \mathrm{cm}^{2}, A M 1.5 \mathrm{G}\right)$ fabricated by the roller painting with different thickness of active layer and the spin coating process, and (b) the corresponding IPCE spectra. All the devices are thermally annealed at $150^{\circ} \mathrm{C}$.

The hole and electron single-carrier mobilities were measured by the standard methods. In the roller painted device, the values of $\mu_{\mathrm{h}}$ and $\mu_{\mathrm{e}}$ are $5.07 \times 10^{-5} \mathrm{~cm}^{2} \mathrm{~V}^{-1} \mathrm{~s}^{-1}$ and $1.75 \times 10^{-4} \mathrm{~cm}^{2}$ $\mathrm{V}^{-1} \mathrm{~s}^{-1}$, respectively, before thermal annealing. These values are comparable to those of the spin coated device after thermal annealing. As shown in Figures 1 and 2, the crystallinity of P3HT in the as-roller painted film is almost the same as that of the spin coated film after thermal annealing. Therefore, it is expected that the holes are transported effectively through the network of P3HT crystals in the roller painted film without thermal annealing. After the thermal annealing, the $\mu_{\mathrm{e}} / \mu_{\mathrm{h}}$ ratio of the roller painted device is decreased from 3.5 to 2.5 . As a result, the mobility mismatch between hole and electron transport becomes smaller and thus the space charge effect becomes diminished in the roller painted device. Due to enhanced and balanced charge conduction in the roller painted P3HT:PCBM film, the high FF of 0.64 was achieved in the roller painted device.

When the nanoscale morphology of the active layer is examined by TEM, the as-roller painted film exhibits interesting morphology, as shown in Figure 4a: very dark, cilia-like nanocrystals (width $\sim 20 \mathrm{~nm}$ and length $\sim 100 \mathrm{~nm}$ ) are clearly observed. It is more interesting to observe that these nanocrystals are well packed and aligned normal to the rolling direction. This morphological characteristic is more pronounced after thermal annealing (see Fig. 4b). These nanocrystals must be grown from PCBM molecules, because PCBM phase is darker 
compared to that of P3HT in bright-field TEM image. The selected area electron diffraction (SAED) pattern also indentifies clearly the PCBM nanocrystal [29], as shown in the inset of Fig. 4b. The fact that PCBM nanocrystals can be developed through simple roller painting is remarkable. These well developed PCBM crystals are expected to contribute to the enhancement of electron mobility in the roller painted device. Although the reason for the morphology difference between the roller painted device and the spin coated one is not clear, it is probably because the shear and normal stresses during the roller painting induces the molecular ordering of PCBM along the direction of the roller painting (Fig. 4a).
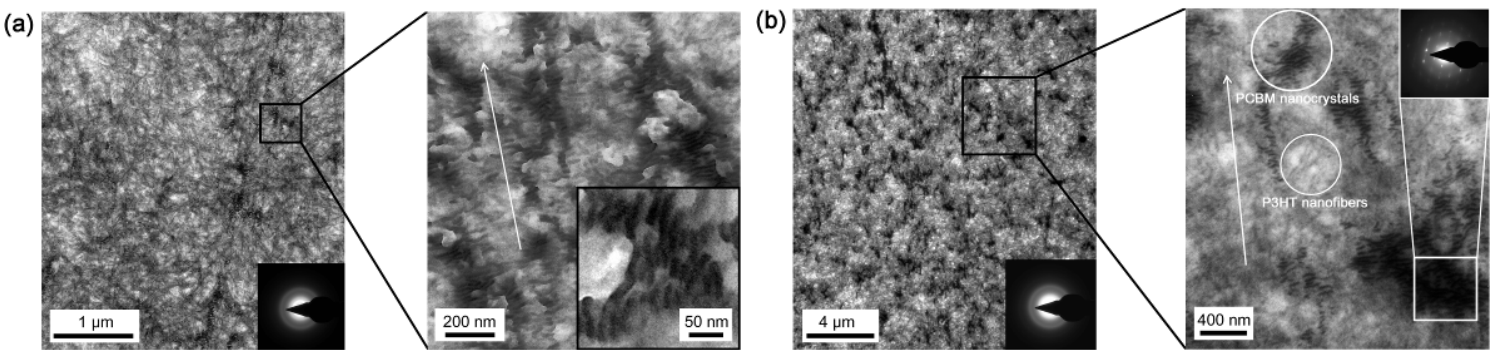

Fig. 4. Bright-field TEM images and the SAED patterns of P3HT:PCBM film fabricated by the roller painting (a) before and (b) after thermal annealing.

Achievement of highly efficient PSC without additional post-treatment is indispensable for industrialzation of PSC. However, most of efficient PSCs based on P3HT and PCBM require an additional treatment such as thermal or solvent annealing which induces phase separation and enhances the crystallinity. Since the additional process increases the fabrication cost of PSCs, development of annealing-free PSC is strongly demanded. Furthermore, high temperature for thermal annealing may not be suitable for preparation of flexible PSCs. Recently, the method of simple blending with an additive, which has lower solubility to PCBM than o-dichlorobenzene and therefore accelerates phase separation of the blend of P3HT and PCBM, has been reported for achievement of high efficiency without thermal annealing. Although the method has achieved around 3\% PCE without thermal or solvent annealing, the PCE value is still lower than the optimized device with annealing process.

We have fabricated the annealing-free large area $\left(5 \mathrm{~cm}^{2}\right)$ PSC device by combining the roller painting process with addition of $5 \mathrm{wt} \% 1,8$-octanedithiol. When the performances of annealing-free devices fabficated by the roller painting are compared with those of spin coated device, the $\mathrm{J}_{\mathrm{SC}}$ and FF of the roller painted PSC are higher than those of the spin coated PSC while $\mathrm{V}_{\mathrm{OC}} \mathrm{S}$ of both processes are almost the same. The PCE of annealing-free device is $3.8 \%$ at the active area of $0.04 \mathrm{~cm}^{2}$. To the best of our knowledge, this value is the higest performance of annealing-free PSCs based on P3HT and PCBM.

\section{Conclusions}

We have fabricated high efficiency PSCs by the roller painting process. Since the roller printing is accompanied with normal and shear stresses and is a slow drying process, it induces effective crystallization of P3HT and PCBM. As a result, the roller painted PSC of $\mathrm{P} 3 \mathrm{HT} / \mathrm{PCBM}$ has achieved $4.6 \%$ PCE, which is $20 \%$ higher than that of the device fabricated by the conventional spin coating process $(3.9 \%)$. This higher efficiency is originated from higher $\mathrm{FF}$ and $\mathrm{J}_{\mathrm{SC}}$ of the roller painted active layer. By addition of small amount of 1,8octanedithiol as an additive, annealing-free PSCs were also fabricated by the roller painting. By combining the roller painting and incorporation of additive, the PCE of $3.8 \%$ was achieved without any post-treatment. This is because the roller painting process enhances the 
crystallization of $\mathrm{P} 3 \mathrm{HT}$ and $\mathrm{PCBM}$, and the additive induces phase separation effectively. To the best of our knowledge, this value (3.8\%) is the best performance of annealing-free PSC based on P3HT and PCBM. Since the PCE of over $2.7 \%$ can be achieved at $5 \mathrm{~cm}^{2}$ active area by the roller painting without post-treatment, it is concluded that the roller painting process is a very promising method for fabrication of large area solar cells. In short, since the roller painting process follows the basic process of the roll-to-roll processing, this research provides a model study for preparation of roll-to-roll processed organic electronics.

\section{References}

[1] C. J. Brabec, N. S. Sariciftci, J. C. Hummelen, Plastic Solar Cells, Adv. Funct. Mater. 11, 2001, pp. 15-26.

[2] G. Yu, A. J. Heeger, Charge separation and photovoltaic conversion in polymer composites with internal donor/acceptor heterojunctions, J. Appl. Phys. 78, 1995, pp. $4510-4515$.

[3] P. Schilinsky, U. Asawapirom, U. Scherf, M. Biele, C. J. Brabec, Influence of the Molecular Weight of Poly(3-hexylthiophene) on the Performance of Bulk Heterojunction Solar Cells, Chem. Mater. 17, 2005, pp. 2175-2180.

[4] Y. K. Kim, S. Cook, S. M. Tuladhar, S. A. Choulis, J. Nelson, J. R. Durrant, D. D. C. Bradley, M. Giles, I. McCulloch, C. S. Ha, M. H. Ree, A strong regioregularity effect in self-organizing conjugated polymer films and high-efficiency polythiophene:fullerene solar cells, Nat. Mater. 5, 2006, pp. 197-203.

[5] P. W. M. Blom, V. D. Mihailetchi, L. J. A. Koster, D. E. Markov, Device Physics of Polymer:Fullerene Bulk Heterojunction Solar Cells, Adv. Mater. 19, 2007, pp. 15511566.

[6] G. Dennler, M. C. Scharber, C. J. Brabec, Polymer-Fullerene Bulk-Heterojunction Solar Cells, Adv. Mater. 21, 2009, pp. 1323-1338.

[7] J. W. Jung, J. U. Lee, W. H. Jo, High-Efficiency Polymer Solar Cells with WaterSoluble and Self-Doped Conducting Polyaniline Graft Copolymer as Hole Transport Layer, J. Phys. Chem. C 114, 2010, pp. 633-637.

[8] G. Li, V. Shrotriya, J. Huang, Y. Yao, T. Moriarty, K. Emery, Y. Yang, . Highefficiency solution processable polymer photovoltaic cells by self-organization of polymer blends, Nat. Mater. 4, 2005, pp. 864-868.

[9] Ma, C. Yang, X. Gong, K. Lee, A. J. Heeger, Thermally Stable, Efficient Polymer Solar Cells with Nanoscale Control of the Interpenetrating Network Morphology, Adv. Funct. Mater. 15, 2005, pp. 1617-1622.

[10] M. Campoy-Quiles, T. Ferenczi, T. Agostinelli, P. G. Etchegoin,Y. Kim, T. D. Anthopoulos, P. N. Stavrinou, D. D. C. Bradley, J. Nelson, Morphology evolution via self-organization and lateral and vertical diffusion in polymer:fullerene solar cell blends, Nat. Mater. 7, 2008, pp. 158-164.

[11] F. C. Krebs, Processing and preparation of polymer and organic solar cells, Sol. Energy Mater. Sol. Cells 93, 2009, pp. 394-412.

[12] F. C. Krebs, Roll-to-roll fabrication of monolithic large-area polymer solar cells free from indium-tin-oxide, Sol. Energy Mater. Sol. Cells 93, 2009, pp. 1636-1641.

[13] Gunes, H. Neugebauer, N. S. Sariciftci, Conjugated Polymer-Based Organic Solar Cells Chem. Rev. 107, 2007, pp. 1324-1338. 
[14] C. J. Brabec, F. Padinger, J. C. Hummelen, R. A. Janssen, N. S. Sariciftci, Realization of large area flexible fullerene - conjugated polymer photocells: A route to plastic solar cells, Synth. Met. 102, 1999, pp. 861-864.

[15] P. Schilinsky, C. Waldauf, C. J. Brabec, Performance Analysis of Printed Bulk Heterojunction Solar Cells, Adv. Funct. Mater. 16, 2006, pp. 1669-1672.

[16] C. N. Hoth, S. A. Choulis, P, Schilinsky, C. J. Brabec, . On the effect of poly(3hexylthiophene) regioregularity on inkjet printed organic solar cells, J. Mater. Chem. 19, 2009, pp. 5398-5404.

[17] D. Vak, S. Kim, J. Jo, S. Oh, S. Na, J. Kim, D. Kim, Fabrication of organic bulk heterojunction solar cells by a spray deposition method for low-cost power generation, Appl. Phys. Lett. 91, 2007, 081102.

[18] C. N. Hoth, R. Steim, P. Schilinsky, S. A Choulis, S. F. Tedde, O. Hayden, C. J. Brabec, Topographical and morphological aspects of spray coated organic photovoltaics, Organ. Electron. 10, 2009, pp. 587-593.

[19] R. Green, A. Morpha, A. J. Ferguson, N. Kopidakis, G. Rumbles, S. E. Shaheen, Performance of bulk heterojunction photovoltaic devices prepared by airbrush spray deposition, Appl. Phys. Lett. 92, 2008, 33301.

[20] K. X. Steirer, M. O. Reese, B. L. Rupert, N. Kopidakis, D. C. Olson, R. T. Collins, D. S. Ginley, Ultrasonic spray deposition for production of organic solar cells, Sol. Energy Mater. Sol. Cells 93, 2009, pp. 447-453.

[21] F. C. Krebs, M. Jorgensen, K. Norrman, O. Hagemann, J. Alstrup, T. D. Nielsen, J. Fyenbo, K. Larsen, J. Kristensen, A complete process for production of flexible large area polymer solar cells entirely using screen printing-First public demonstration, Sol. Energy Mater. Sol. Cells 93, 2009, pp. 422-441.

[22] S. Kim, S. Na, J. Jo, G. Tae, D. Kim, Efficient Polymer Solar Cells Fabricated by Simple Brush Painting, Adv.Mater. 19, 2007, pp. 4410-4415.

[23] J. W. Jung, W. H. Jo, . Annealing-Free High Efficiency and Large Area Polymer Solar Cells Fabricated by a Roller Painting Process, Adv. Funct. Mater. 20, 2010, pp. 23552363.

[24] G. Derue, S. Coppee, S. Gabriele, M. Surin, V. Geskin, F, Monteverde, P. Leclere, R. Lazzaroni, P. Damman, Nanorubbing of Polythiophene Surfaces, J. Am. Chem. Soc. 127, 2005, pp. 8018-8019.

[25] H. Sirringhaus, P. J. Brown, R. H. Friend, M. M. Nielsen, K. Bechgaard, B. M. W. Langeveld-Voss, A. J. H. Spiering, R. A. J. Janssen, E. W. Meijer, P. Herwig, D. M. De Leeuw, Two-dimensional charge transport in self-organized, high-mobility conjugated polymers, Nature 401, 1999, pp. 685-688.

[26] R. Osterbacka, C. P. An, X. M. Jiang, Z. V. Vardeny, Two-Dimensional Electronic Excitations in Self-Assembled Conjugated Polymer Nanocrystals, Science 287, 2000, pp. 839-842.

[27] M. Kim, B. Kim, J. Kim, Effective Variables To Control the Fill Factor of Organic Photovoltaic Cells, ACS Appl. Mater. \& Interfaces 1, 2009, pp. 1264-1269.

[28] G. Lu, L. Li, X. Yang, Creating a Uniform Distribution of Fullerene $\mathrm{C}_{60}$ Nanorods in a Polymer Matrix and its Photovoltaic Applications, Small 4, 2008, pp. 601-606. 